\title{
KAUWAERANGA IN CONTEXT
}

\author{
Fergus Sinclair*
}

Much controversy throughout the world has surrounded aboriginal territorial and nonterritorial rights. In New Zealand, the decision last century of Chief Judge Fenton in Kauweranga has been upheld as a major precedent for non-territorial Maori fishing rights. The author explores in much greater detail than before the circumstances of the decision, and claims that without such an examination old authorities such as Kauwaeranga will be of limited value.

\section{INTRODUCTION}

The Kauwaeranga decision was delivered in 1870 by F D Fenton, Chief Judge of the Native Land Court. The judgment has often been discussed in the literature generated by Maori claims. Opinions differ. It has been lauded as a recognition of Maori fishing rights and a precedent for the existence of "non-territorial" aboriginal titles in New Zealand. It has also been portrayed as ushering in a more conservative approach to foreshore claims, and Fenton has been attacked for bending to policy considerations in refusing to issue a freehold title. The case is likely to attract continued attention, but it appears that it is not well understood. An attempt is made here to explore the context and impact of the decision and discuss its treatment in recent commentary. ${ }^{1}$

One misapprehension may be dealt with at once. It has been said that the Native Land Court in the 1860s "awarded some important tidal areas to various Maori as property rights and not merely as rights to fish." 2 The basis for this view appears to be the Whatapaka case which was referred to in the Waitangi Tribunal's Manukau Report. ${ }^{3}$ Whatapaka involved a piece of land alongside the Manukau harbour and a shell bank

* Barrister and Solicitor of the High Court of New Zealand, Wellington.

1 Most of the research for this article was conducted in 1989-90. Since that time, I have had the benefit of reading various publications by R P Boast and the claimant evidence in the Hauraki claim. Although helpful, this material does not refer to primary sources of which I was unaware. Whenever possible I have cited the archival locations of primary documents. I am grateful to J B Parker for his help with the research.

2 Waitangi Tribunal Muriwhenua Fishing Report 1988, 84.

3 Waitangi Tribunal Manukau Report 1985 paragraph 6.2. 
separated from the mainland by a channel of water. The surveyor testified to the court that the bank was not covered at ordinary high tide but was covered by spring tides. ${ }^{4}$ The inclusion of this area in the court's order was therefore not an award of the foreshore which, under the definition then applicable, began at mean high water mark. An official return of Crown grants to the foreshore published in 1868 does not list any grant to a Maori owner. ${ }^{5}$ The novelty of a Land Court claim to the foreshore proper was alluded to in Kauwaeranga, which Fenton described as "the first case of the kind that has occurred in the colony." 6 There is no reason to suppose that the Chief Judge was incorrect. ${ }^{7}$

\section{BACKGROUND TO KAUWAERANGA}

The foreshore opposite the towns of Shortland and Grahamstown (now Thames) was a broad mudflat formed by sediments from the Waihou and Kauwaeranga rivers. It was an important flounder fishing ground. Godwits and shellfish were also taken. In times past, stakes had been driven into the mud to support fishing nets. ${ }^{8}$ By 1870, these had mostly been broken off by ships, but there apparently remained some stone walls associated with the fishing. ${ }^{9}$ It seems that the mudflat was difficult to cross by foot except near the beach, and there had been some encroachment by the sea over what had once been dry ground. ${ }^{10}$

The land next to the foreshore was still in Maori hands, but was subject to an agreement signed in 1867 that enabled the area to be administered as a goldfield. There had been rapid development of the Thames field. Townships had been laid out and rents were paid to the Maori owners, who had divided the land into parcels and obtained certificates from the Native Land Court.

4 Native Land Court, Auckland Minute Book 1 pp 110-111.

5 [1868] AJHR C-3.

6 A Frame "Kauwaeranga Judgment" (1984) 14 VUWLR 227, 244.

7 Richard Boast has claimed that "despite Chief Judge Fenton's repudiation of the practice in the Kauwaeranga decisioán, the Land Court granted a number of freehold (ie not merely fisheries) titles to areas between high and low-water mark. These grants of freehold title to areas below high-water mark were also mainly in the Thames area." R P Boast "In Re Ninety Mile Beach Revisited: The Native Land Court and the Foreshore in New Zealand Legal History" (1993) 23 VUWLR 145, 152. I have viewed the material referred to without finding any documentation to support this assertion. It may be that there has been some confusion with purchase deeds relating to the variously named parcels of the Thames foreshore. [1869] AJHR F-7 7.

9 Native Land Court, Hauraki Minute Book 4, 210.

10 A Frame "Kauwaeranga Judgment" (1984) 14 VUWLR 227, 229. 
It soon became known that the auriferous reefs extended beneath the mudflat. James Mackay, who had negotiated the mining agreement and acted as Warden of the new goldfield, was asked to register a claim over parts of the foreshore. Mackay seems to have thought that his 1867 agreement did not apply below high water mark. In any event, he was instructed by the Provincial Government to decline the application and receive no more. ${ }^{11}$

The uncertain status of the Thames foreshore came to the attention of the General Government. With a view to clarification, section 9 of the Gold Fields Act Amendment Act 1868 provided that land below high water mark could be included in a gold field, but where such land abutted land over which the native title was unextinguished, or which was held under a certificate from the Native Land Court, "such land so lying below high-water mark shall for the purposes of this Act be deemed to be land over which the Native title has not been extinguished." This section apparently reflected the view of the Native Minister, J C Richmond, that the prerogative right to the foreshore ought not to apply where the adjoining land remained in Maori possession. ${ }^{12}$ Richmond's directions to Mackay advised him: ${ }^{13}$

...that this land is in an exceptional legal position. The Native title over it would probably not be recognized by courts of law; at the same time, it is not within the definition of Crown Land, or subject to the ordinary Waste Land laws. The Gold Fields Act of this Session points out how it may be dealt with - ie by agreement between the Colonial Government and the Native owners of adjacent land.

Mackay was instructed to "arrange with the Native owners for the occupation of this tidal flat upon reasonable terms". ${ }^{14}$

The Government had hoped that section 9 would prevent any private party from treating with Maori for rights in the foreshore. It did not, however, deter such negotiations, and at the same time Mackay made little progress towards securing the beach for the Government. ${ }^{15}$

Concern at these developments led the new Fox ministry to introduce the Thames Sea Beach Bill in 1869. The Bill was intended to remove any doubt about the Crown's prerogative right to the beach by declaring it to be Crown demesne. Private dealings

11 [1869] AJHR F-7, 7.

12 (9 Oct 1968) 4 NZPD 248 and (1 Sept 1869) 6 NZPD 903.

13 G S Cooper to Mackay, 9 August 1869, [1869] AJHR, F-7, 15.

14 Above $\mathrm{n} 13$.

15 [1869] AJHR F-7, pp 7-8. 
were to be forbidden; the Government could let or sell the land, and any miners' right fees would be paid to the Maori owners of the adjoining land. ${ }^{16}$ The Select Committee on the Bill heard considerable evidence and counselled a different approach. It reported that legislation should be delayed until the question of Crown and Maori claims upon the foreshore and precious metals had been resolved. In the meantime, the Government should make an arrangement with Maori to obtain control of the Thames foreshore. ${ }^{17}$

A more limited measure was substituted and passed as the Shortland Beach Act 1869. This prohibited private dealings over the foreshore and invalidated past dealings. It was apparently expected that the Act would merely freeze the position until further legislation could be introduced. The debate on the Bill is of some interest, particularly for Richmond's comments as to why it was too late to assert the Crown's prerogative in its strictest form. He observed that, in various ways, there had been a relaxation of prerogative claims over the mainland since at least 1846. It was strange therefore that:

...this wretched little strip of land on the Shortland beach was now, on the plea of prerogative rights unknown and incomprehensible to the Natives, to cause a renewed assertion of those beneficial rights which we had abandoned as to every other part of the Colony.

He went on to explain that the waiver of any Crown claim to beneficial ownership of the foreshore in this case would not represent a great sacrifice, because: ${ }^{18}$

[a]11 the great ports of the Colony, for all present purposes, had been alienated by the Natives. There never was, he believed, in their minds, any doubt that, in alienating the terra firma, all that abutted upon it on the coast was also alienated, unless there was a special reservation. The fact that there was such reservation in some cases, showed that total alienation was the rule.

\section{WHAKAHARATAU AND KAUWAERANGA - 1870}

Before the Thames foreshore claims were heard in 1870, there was no history of Native Land Court cases concerning the foreshore proper. The Gold Fields Act Amendment Act of 1868 had raised an implication that the foreshore opposite Shortland would be regarded as subject to native title. The actions of the Government in treating with Maori for control of the beach seemed to confirm that the Crown's prerogative would not be strictly applied. Parliament had excluded individuals from acquiring rights in the foreshore at Thames, but had otherwise left open the question of Crown and Maori rights.

16 (3 August 1869) 6 NZPD 196.

17 [1869] AJHR F-7, 3.

18 (1 Sept 1869) 6 NZPD 903. 
So matters stood when Chief Judge Fenton heard the first application to a piece of Hauraki foreshore in May. The portion claimed was called Whakaharatau and was slightly more than an acre. It seems likely that it was a portion of Whakaharatau A No 1, which adjoined Shortland and was later the subject of an award under the principle laid down in the Kauwaeranga case. The land was entirely below high water mark, but had once been dry ground on which four houses had stood. The claimant, Rawira Te Wahapu, spoke about fishing and pipi-gathering but seemed to indicate that these activities had occurred away from the land in question.19

The court was addressed by counsel for the claimants on the advisability of referring the question of the Land Court's jurisdiction to the Supreme Court. Fenton gave a short judgment because he thought that only a decision of the Supreme Court would be of any use as a precedent. ${ }^{20} \mathrm{He}$ briefly stated that he could find no reason at law that prevented a Maori from owning land covered by the sea at high water - "the question of ownership of any portion of the foreshore by a Maori must depend simply on a question of fact." 21 On this occasion, he held that no ownership had been proved except for the portion on which the houses had formerly stood, but as it was accepted that the case must stand or fall as a whole, he dismissed the application.

It has been suggested that Fenton's reference to ownership being purely a question of fact was a recognition that Maori might own the fee simple of the foreshore, and that he

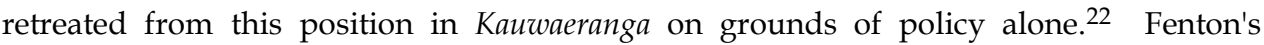
observations were, in a sense, merely obiter because the facts did not oblige him to make a definite pronouncement on the law. But in any case, the argument overlooks the next sentence in his decision which states: ${ }^{23}$

At the same time I do not suppose that the Maoris would have ever claimed any right over such land except in the few cases where they had used it in the way of sole property for fisheries...

19 Native Land Court, Hauraki Minute Book 4, 191. The witnesses' statements about pipi-gathering appear ambiguous in the minutes, but there was apparently no fishing with nets on the land before the court.

20 Native Land Court, Hauraki Minute Book 4, 201, 203.

21 Above n 20, 202.

22 A Frame "Kauwaeranga Judgment" (1984) 14 VUWLR 227, 239 note 3. A Parsonson "The Challenge to Mana Maori", in G W Rice (ed) The Oxford History of New Zealand (2ed, Oxford, Auckland, 1992) 194. Muriwhenua Fishing Report 84.

23 Native Land Court, Hauraki Minute Book 4, 202. 
This remark contains the germ of his reasoning in Kauwaeranga and it is difficult to see any major inconsistency between the two judgments.

In Kauwaeranga, Fenton contrasted the result in Whakaharatau with the evidence of consistent and exclusive use now before him. This suggests that the applicant in Whakaharatau had simply failed to meet an evidential threshold that was satisfied in other cases involving the same foreshore. In an earlier, private letter to Donald McLean, however, Fenton suggested that the Whakaharatau decision would mean, in effect, that the Shortland foreshore as a whole would vest in the Crown. He was concerned that the Government's continued attempts to buy out Maori claims would be seen as undermining the court's decision and lead to European speculators stirring up other claims around New Zealand - "[t]hat stupid clause of Richmond's in the Gold Fields Act is the cause of all this bother". ${ }^{24}$ The Government's response was that it never intended to forgo the Crown's right to the land below high water mark but, in view of the expectations raised by the Gold Fields Act 1866 and actions by the previous ministry, it would only be fair to pay compensation "for the supposed rights of wh[ich] they are deprived." 25 In any case, the negotiations had broken down by August 1870, for reasons unconnected with the Whakaharatau judgment. ${ }^{26}$

Fenton did not rule out all Maori claims to the foreshore, instancing a famous pipi ground about a mile away "which perhaps they may get but it is not certain." ${ }^{27}$ It is not clear why he thought at this stage that other claims to the Shortland beach would fail, but his private comments to McLean suggest that, contrary to what is usually asserted, Kauwaeranga represents a more liberal approach on his part.

The foreshore question again came before the Native Land Court at Shortland on 8-11 November. Fenton first heard claims by Nikorima Poutotara and others to portions of the beach opposite Grahamstown - the applications that would lead to the Kauwaeranga decision. He ordered certificates in favour of the successful claimants "for the right they exercised" but left open the question of "whether they owned below the surface". ${ }^{28}$ The foreshore adjoining Shortland was the subject of an overarching claim by the Ngati Rautao chief, Hotereni Taipari, and some twenty others whose rights he admitted.

24 Fenton to McLean, 16 August 1870, MS 32, folder 267, Alexander Turnbull Library.

25 G S Cooper to the Civil Commissioner, Auckland, 3 September 1870 (draft) N S 70-1112, MA 1 1872/1854, 7, National Archives.

26 H T Clarke to McLean, 24 August 1870, MS 32, folder 217, Alexander Turnbull Library.

27 Fenton to McLean, 16 August 1870, MS 32, folder 267, Alexander Turnbull Library. 
Taipari asserted ownership "irrespective of the ownership of the land adjoining". ${ }^{29} \mathrm{He}$ was opposed by the owners of certain sections on the mainland (apparently members of Ngati Whanaunga and other tribes). The contention of these people, as reported in the Daily Southern Cross, was that "if they owned the solid ground, the mud flat opposite must be theirs also, or at least the fisheries, and pipi banks thereto appertaining." 130

The court decided against Taipari's wider claim and indicated it would award rights to all the owners of the adjacent shores. The tidal beds of the Kauwaeranga River, being land below low water mark, were excluded. ${ }^{31}$ The character of the rights to be recognised was again left open. Some preliminary argument was heard on this point on 11 November, but the Crown having expressed a wish to be heard, the matter was adjourned for a sitting at Auckland later that month. The arguments of counsel are recorded in some detail both in the court minutes and the Daily Southern Cross. ${ }^{32}$ Fenton reserved judgment and, not for the last time, expressed his anxiety for the issues to be decided by the Supreme Court.

The Kauwaeranga decision was delivered on 3 December. It is reproduced in a number of easily accessible sources and there is no need to dwell on the Judge's lengthy recitation of historical events. ${ }^{33}$ As is well known, Fenton declined to make an order vesting the soil of the foreshore absolutely. He held instead that the interest owned by the Maori was an exclusive right of fishery. The Government's negotiations were "not needed to strengthen the case of the claimants, for it has not appeared what rights the Government recognised, and they may be the same that the court awards."134 The Gold Fields Act Amendment Act 1868 was, he noted, limited to the purposes of that Act, and Parliament had not yet passed any law on the matter, as was contemplated when the Shortland Beach Act was passed.

The precise form of the awards was settled at a further hearing on 24 May 1871. The court adopted the Crown's proposal that the certificates should contain the words: ${ }^{35}$

29 Native Land Court, Hauraki Minute Book 4, 217.

Daily Southern Cross, 15 November 1870, 3.

31 Native Land Court, Hauraki Minute Book 4, 229.

33 A Frame "Kauwaeranga Judgment" (1984) 14 VUWLR 227.

34 "Kauwaeranga Judgment', reprinted from the Daily Southern Cross, Hocken Library, 11. The version at (1984) 14 VUWLR 227, 245 omits the second word "not".

35 Native Land Court, Hauraki Minute Book 4, 239. 
... the exclusive right of fishing upon and using for the purpose of fishing, whether with stake nets or otherwise the surface of the soil of all that portion of the foreshore or parcel of land between high water mark and low water mark.

The effect of these orders was the division of the foreshore into parcels corresponding to the sections on dry land, the exclusive right of fishing being vested in the owners of those sections. ${ }^{36}$ In some cases the parcels were long thin rectangles of beach. Individuals such as Taipari (who had one of the least valuable areas) owned rights over several hundred acres of mudflat. ${ }^{37}$

Fenton detained the certificates while waiting to hear if his judgment would be appealed. The claimants had still not ruled out an appeal by August 1871, but by this time the Government had renewed its overtures to buy the Maori rights. ${ }^{38}$ E W Puckey, who was entrusted with this task, found it hard to secure the mudflat in one offer, and predicted more success in buying the rights separately. ${ }^{39}$ The main obstacle was Rapana Maunganoa, who, urged on by his son-in-law David Stewart, successfully held out for a sum of $£ 1,500$. By the end of 1873 the government had paid more than $£ 2,800$ in extinguishing Maori claims over the Thames foreshore. ${ }^{40}$ Two forms of wording were used in purchase deeds. Some documents recited the rights conferred by the Native Land Court and recorded the conveyance of those rights to the Crown. Most of the deeds signed after 1871 contained the formula:

... the said natives doth hereby convey... All that portion of the foreshore or parcel of land between high-water mark and low-water mark.... with all the rights and appurtenances thereunto belonging And all other estate right title interest and demand whatsoever if any of the said Native in and to the said foreshore... unto Her Majesty... Provided always that this deed and nothing herein contained or implied shall be deemed in any way to infringe upon or affect the undoubted prerogatives of Her said Majesty... as the sole and absolute sovereign of the whole territory of New Zealand its shores and waters...

36 This appears to be the arrangement sought by the Coromandel claimants also. See brief of evidence, "Coromandel Foreshore", MA MLP 1 82/5, National Archives.

37 H T Clarke to McLean, 6 August 1870, MS 32, folder 217, Alexander Turnbull Library.

38 Daily Southern Cross, 7 August 1871.

39 E W Puckey to McLean, 5 August 1871, MS Papers 32, folder 518, Alexander Turnbull Library.

40 Daily Southern Cross, 11 October 1871. E W Puckey to McLean, 14 July 1871, 17 July 1872, MS Papers 32, folder 518, Alexander Turnbull Library. Payments recorded in AP2/21, National Archives, and AJHR, 1873, G-3, no 11, p 16. 


\section{THE COROMANDEL FORESHORE CASE AND MOVES TO LEGISLATE}

Following his Kauwaeranga decision, Fenton continued to urge upon McLean the need for an appeal or legislation to settle the issue of Maori rights in the foreshore. ${ }^{41}$ In turn, McLean sought the advice of the Attorney-General: should the case be removed to the Supreme Court and did the Native Land Court have jurisdiction to make such award? McLean also wondered: ${ }^{42}$

if... the Government would be justified in accepting from the natives a deed of cession of the beach not recognising any absolute title, which might form a dangerous precedent; but giving compensation for the loss of fishing and other rights exercised by them over the foreshore.

The Attorney-General's reply has not been located. ${ }^{43}$

The matter was aired in the press. A correspondent to the Daily Southern Cross discussed the merits of foreshore claims and concluded: ${ }^{44}$

There is pressing necessity for the consideration of this question by the Assembly, and for the enactment of some law by which the rights in these cases would be clearly defined. What is required is not an arbitrary enactment ignoring altogether native title to any part of the foreshore and excluding applications from the court, but such provision should be made, by defining plainly the question of what constitutes a valid claim to the foreshore, as will enable the court to decide any cases that may arise. The Assembly has hitherto ignored this subject, although attention has been repeatedly drawn to it. Partly no doubt this has arisen from the many difficulties which surround the subject, but another session should not be allowed to pass without the whole question being considered.

As it happened, events at Coromandel soon obliged the Government to take action.

It is unsurprising that the partial success of the Kauwaeranga claimants and the sums being offered by the government encouraged other foreshore claims in the Hauraki area. Further north, at Coromandel, the beach had also been pegged out by miners. ${ }^{45}$ Much of the adjacent land had passed out of Maori hands through old land claims and the

41 Fenton to McLean, undated, MS Papers 32, folder 267, Alexander Turnbull Library.

42 McLean to the Attorney-General, 1 April 1871, No 111/1, MA 4/14, pp 354-355, National Archives.

43 See Baker to the Native Minister - 17 April 1871, MA 4/14, 351, National Archives. This enclosed an opinion of the Attorney-General on Fenton's decision which was expected to answer the Native Minister's enquiries.

44 Daily Southern Cross, 17 April 1872.

45 Daily Southern Cross, 17 April 1872. 
Crown's purchase of the Patapata block in 1857. At least two blocks fronting the harbour, Te Ngorongoro and Te Umuhau, were still in Maori ownership in 1871. These blocks were brought before the Court in June. The surveys of both contained portions of the adjoining mudflat down to low water mark. The Court ordered certificates that excluded the mudflat below ordinary high tides. It advised the applicants that if they wished the mudflat to be investigated they must put in a separate claim afterwards. ${ }^{46}$ Further claims, apparently to a larger area of mudflat, were duly heard in May $1872 .{ }^{47} \mathrm{~J} \mathrm{C}$ MacCormick appeared for the Crown and produced a proclamation suspending the Court's jurisdiction over land below high water in the Province of Auckland. The Government, he explained: ${ }^{48}$

...think it necessary to the public good to suspend for a time the hearing of these claims to the foreshore at Coromandel. It is considered that if these portions of the foreshore were given to the natives a great wrong would be done to the people living at Coromandel, and particularly to the Europeans who own land there fronting the harbour. It would not be right for the natives, after they have sold the land bounded by the sea-shore, to come now and ask to have the right to use the sea-shore taken away from those persons and given to the natives alone, as the claimants here are doing. This is a new thing, this claiming the use of the sea shore for the natives only; it was not heard of before gold was found on the beach, and the Government must take time to consider which is best to be done both for the Maori and the European in the matter. It may be necessary that the question of what is to be done with all claims by the natives to the seashore should be considered in the General Assembly, where there will be natives to take part in the deliberations upon it. I am, therefore, instructed to impress upon the natives that the hearing of these claims is only deferred, not refused; and that the Government have not the wish, as they certainly have not the power, to deprive the natives of any just rights they may have to the foreshore.

MacCormick offered to pay the reasonable expenses of the Maori who had come to Auckland for the case, but warned "they must distinctly understand the Government do not acknowledge any claim. ${ }^{49}$ McLean's reason for this step was that: ${ }^{50}$

it appeared that these claims were only the forerunners of others likely to be put forth extending over a much wider area, and embracing so large an extent of property that with a

46 Native Land Court, Coromandel Minute Book 2, pp 208-209.

47 The applications for the Coromandel foreshore blocks nos. 1-5 were advertised in the Kahiti on 13 and 27 December 1871

49 Above $\mathrm{n} 48$

50 In Re The Ninety-Mile Beach [1963] NZLR 461, 479. The original source has not been identified. 
view to the necessary protection of the important interests involved it was desirable to place such restrictions as were allowed by law upon the action of the court pending the passing of a declaratory Act by the Legislature.

The New Zealand Herald called for immediate action from the government. If the claims succeeded, "any person walking over any portion of this foreshore would become a trespasser." 51 The Herald cited a "well known legal treatise" that doubted the legitimacy of private titles to the foreshore. It also questioned Fenton's assessment of the evidence in Kauwaeranga.

J C MacCormick came to the court's defence in the next issue. He noted that in Whakaharatau, Fenton had decided against the claimant because no exclusive right of use had been proved. But in Kauwaeranga, the claimants "were not wanting with the evidence required, and, as lawyers sometimes say, swore up to the mark, while, unfortunately, no counsel was employed on behalf of the Crown to cross-examine them." 52

Fenton was therefore obliged to take the facts sworn to as proven. Moreover, the Shortland Beach Act 1869, which MacCormick considered "a very impolitic and unadvised measure" appeared to "have recognised certain rights in the natives to the Shortland Beach." 53 He did not think that Kauwaeranga would be treated as a precedent by the court, at least outside the boundaries affected by the Act.

The Herald accepted that there was a significant difference between the Thames and Coromandel cases: ${ }^{54}$

The natives had not alienated their land at Grahamstown and Shortland; but they have alienated the greater portion of their lands abutting on Coromandel harbour. In all such cases, we hold that the foreshore belongs of right to the Crown... When we state that among the claims to be heard by the Native Lands court is one to the foreshore at Preece's Point, for which land a Crown grant was issued in 1842, our meaning will be clear. If this claim holds good, a similar claim would hold good for any portion of the harbour of Auckland.

The paper remained sceptical of the authenticity of the Coromandel claims, and repeated its caution to the Native Land Court: ${ }^{55}$

51 New Zealand Herald, 15 April 1872.

52 NZ Herald, 16 April 1872.

53 Above n 52.

54 Above $\mathrm{n} 52$.

55 Above $n$ 52. Italics in original. 
The Judges... will also pardon us for suggesting that it would be well to consider the probabilities in determining the truth of any statement. It is hardly probable, that if a native owned such a valuable property as the exclusive right to use a portion of the sea shore as a fishery, no one should hear of it for a period of thirty years, and then only when a goldfield was discovered in the immediate vicinity.

The Daily Southern Cross, which had considered that the Maori claims at Kauwaeranga were fair, also saw serious consequences arising from the Coromandel applications: ${ }^{56}$

The Coromandel claims introduce a feature that has not before cropped up, and will show those of our readers who are not acquainted with the nature and effect of those beach claims how important they are. A very large portion of the beach which is the subject of the pending actions, fronts land purchased by private individuals years ago, and over which the native title has altogether been extinguished. The township of Kapanga is one portion of this property. Now, supposing that this township had been extensively built upon, and the native claims to the beach were subsequently recognised, the entrance to the place would have been completely blocked up. Indeed there is nothing to prevent such claims being made for portions of the beach abutting on the Waitemata harbour, and when it is considered how easy it might be for the natives to prove that their ancestors had fishing grounds in Mechanics', St George's, Judge's, or Freeman's Bay, we cannot be at all certain that such claims will not actually be made, unless the law is so framed as to render such claims inadmissible. We believe the Government are preparing to deal with this grave question, and that the bill will be brought forward next session of the Assembly. The question is altogether a difficult one to deal with, for, while it is necessary that the public interests involved should be stringently protected, it would be unfair under all the circumstances to deprive the natives of their rights to fisheries which may be of great value to them. We think, however, that whatever provision may be made in the bill for the recognition of such rights it should be held that wherever the natives have disposed of land abutting upon the seashore, whether by sale or otherwise to the Crown or to private individuals, such alienation should be regarded as a tacit relinquishment of all claim to the beach in front of the property disposed of, unless there was a distinct understanding to the contrary at the time of the sale.

A declaratory act was drawn up, though not introduced. No copy has been located and the content of the Bill must be deduced from MacCormick's letter to McLean enclosing a draft "to provide for claims by natives to the sea-shore." ${ }^{57}$ McLean had

56 Daily Southern Cross, 16 May 1872.

57 J C MacCormick to McLean, 11 July 1872, MS 32, folder 406, Alexander Turnbull Library. Underlining in original. Fenton seems to have included clauses dealing with foreshores and auriferous lands in his draft Native Lands bill. He suggested to McLean that these remain in the draft because "I don't know what is the mind of the government on these questions." Fenton to McLean 8 June (or January) [1871?], MS Papers 32, folder 267, Alexander Turnbull Library. 
apparently suggested that while the measure "should provide for any real claims which the natives might have it should not invite claims." ${ }^{18}$ If passed in its existing form MacCormick was sure it would "do full justice to the natives \& at the same time prevent their claims being made the means of robbing the public for the benefit of pakeha speculators." He added: ${ }^{59}$

I have made the provisions of the Bill as general as possible so that it should not be said it was directed against the natives. Clauses 14 to 20 provide for the granting of the fore-shore in certain cases \& they will apply to natives holding land under the Crown as well as to British subjects. These clauses can of course be omitted from the Bill if there were any danger of the passing of the Bill being defeated by their remaining, but I think it desirable they should stand \& the Superintendent [of Auckland Province] approves of them.

There are risks in drawing inferences from such a brief description, but it is likely that the Bill asserted the Crown's general right to property in the foreshore - at least where native title over the dry ground was extinguished - while authorising grants to be made in special circumstances. Maori "holding land under the Crown" might qualify for such grants, which suggests that ownership of adjoining land was a prerequisite.

McLean's failure to introduce the Bill was possibly related to the temporary ousting of the Fox ministry - of which he was a member - in September 1872. Foreshore rights were still exercising the Government in March of the next year, when Fox (in McLean's absence) requested Fenton: ${ }^{60}$

To make the following enquiry from the Judges of your Court and report the result to this office at your earliest convenience.

Do they, or any, and which of them, decide that lands below high water mark are Native lands, though such lands are adjacent to lands over which the Native Title has been extinguished by previous cession to the Crown, - and, if so, on what grounds?

Do they, or any, and which of them, in any case decide that lands below high water mark are Native lands and find Natives entitled thereto and grant certificates for such lands?

Gisborne's correspondence to McLean reveals that he and James Prendergast were involved in considering the draft bill on foreshores.

59 Above $\mathrm{n} 57$.

60 GS Cooper to Fenton, 29 March 1873, MA 4/17, National Archives. 
Fenton's reply appears not to have survived. ${ }^{61}$ It is reasonable to suppose, however, that the Land Court judges would not award rights to Maori when the adjoining land had passed from their hands. The later history of the Coromandel claims would suggest that this was so. If the reply to Fox's inquiry was along these lines, the Government may have decided that legislation was unnecessary and the court could continue to award fishing rights in appropriate cases where Maori retained the adjacent land.

It has been contended that the 1872 Proclamation reflected alarm at the implications of Kauwaeranga, and that it blocked the Coromandel claims and destroyed a jurisdiction that might have recognised legitimate Maori claims. ${ }^{62}$ These interpretations are questionable. The proclamation was avowedly a temporary measure that was not intended to frustrate further Maori claims. It lapsed when the Native Lands Act 1873 came into effect. ${ }^{63}$

Despite the concern about Maori claims abutting European land, the Government authorised the purchase of the Coromandel foreshore in 1874. This seems to have been an act of expediency to remove any opposition to the mining of the mudflat. The sums paid to the claimants were certainly more modest; over the next four years around $£ 200$ was spent in extinguishing their claims. ${ }^{64}$

In 1879 the Crown applied to have its interest in the Coromandel foreshore defined by the Native Land Court. Judge Monro deferred the matter, preferring that Fenton hear the case and suggesting that the claimants also make an application. This caused some embarrassment to the Land Purchase Agent, G T Wilkinson, who had brought some claimants from Waiheke to complete the Crown's title. ${ }^{65}$

The Crown's application was heard again on 30 November 1881 and dismissed. No minute of this hearing has been located. The only record of the case merely states: "Native title not found."66 As the court had power to determine the Crown's interest in any piece of land, the likely explanation for this result is that any Maori interest in the

61 See register entry at MA 1 1873/2003, National Archives. Judge Monro also replied and Judge Smith indicated that he had "never adjudicated." MA 1 1873/2342 and 1873/2560, National Archives.

62 Muriwhenua Fishing Report, para 5.4.1. Evidence of A Ward, WAI 27, AA 26, pp 8, 38.

63 In Re the Ninety-Mile Beach [1963] NZLR 461, 474. R Boast describes the revocation as inadvertent. Above $n 7$ 152. There seems to be no evidence that this was so, and MacCormick made it clear in 1872 that the prohibition was not to be permanent. The later handling of the Coromandel claims shows that Crown employees were aware that the Court's jurisdiction had been restored. NLP 78/1426 in MA/MLP 1 82/5, National Archives.

65 G T Wilkinson telegram to R J Gill, 20 November 1879, MA MLP 1 82/5, National Archives. 
foreshore was deemed to be extinguished by purchases of the adjoining land. ${ }^{67}$ Shortly afterwards the Native Minister brought the Crown application to the attention of the Chief Judge, but there is no record of further action on the matter. ${ }^{68}$ There were, however, several Maori applications for portions of the Coromandel foreshore in 1886. These were dismissed for lack of the necessary plans. ${ }^{69}$ A further application by Wiremu Taipua in 1889 was adjourned at his request. The outcome of his claim has not been discovered. ${ }^{70}$

\section{LATER DEVELOPMENTS}

It is hard to assess awareness of the Hauraki foreshore cases among Maori in other parts of the country. There is some evidence that the Kauwaeranga decision was reasonably well known. In the far south of the country, Riverton Maori made reference to the Thames awards when asserting ownership of the foreshore opposite their reserve in 1874. They argued that the reserves in the Murihiku block were lands over which native title had never been extinguished, therefore they possessed an exclusive right to the adjoining foreshore. ${ }^{71}$

Wi Parata also alluded to the Thames awards when he claimed the Porirua foreshore in 1880. His application covered some hundreds of acres of mudflat in the southern part of the harbour, opposite land that had been set apart for Maori under the 1847 Porirua purchase. ${ }^{72}$ The case was delayed for various reasons and judgment was given by Chief Judge MacDonald in 1883. Although his decision noted the lack of opposition from the Crown, he had prevented Alexander Mackay from producing the New Zealand Company deeds to the area. ${ }^{73}$ He found that the applicants had been accustomed to gathering pipis, but had exercised no other rights: ${ }^{74}$

67 Native Land Amendment Act 1877, s 6

68 See draft letter 397/4 in MA/MLP 1 82/5, National Archives.

69 Native Land Court, Coromandel Minute Book 4, 50.

70 Native Land Court, Coromandel Minute Book 5, 33

71 See Alexander Mackay's report on the dispute, [1874] AJHR G-5C, 1-2. There had apparently some threat to fence the foreshore opposite the reserve. Telegram to Horomona Parata, no 435, MA 5/2, National Archives.

72 Native Land Court, Wellington Minute Book 1, 74,75, 83,102. ML Plan 496, LINZ, Wellington.

73 Native Land Court, Wellington Minute Book 1, 157. It is hard to see the relevance of these since the extinction of native title ultimately rested on the Porirua purchase in 1847.

74 Native Land Court, Wellington Minute Book 1, 157-158. 
Under these circumstances if the judgment of the court in the matter of the Shortland foreshore be correct and it has not been impeached it is clear that the present applicants are entitled not to the land but to a right of fishery, the collection of pipis being taken by the judgment referred to as a "fishery" and so this court finds.

Though this court incidentally finds as above ie that the applicants are entitled to an incorporeal hereditament it yet remains to be shown that the court has any jurisdiction to deal with the Title thereto.

Kauwaeranga did not, however, produce a spate of foreshore cases. This was despite a high level of concern about foreshore issues in the north of the country during the late 1870s and 1880s. The Hauraki claims themselves were limited to discrete portions of the foreshore rather than long areas of coastline. They concerned those portions where the recognition of an interest was likely to yield a pecuniary reward because of the presence of gold.

\section{FENTON ELABORATES HIS PRINCIPLE}

Fenton enlarged on the principle he had laid down in Kauwaeranga when appearing before the Native Affairs Committee in 1880. When asked about the practice of the court in dealing with fisheries he replied: ${ }^{75}$

The rule of law [laid down by the Court] is simply this - when I say rule of law I mean Maori common law - that where a native, native family, or tribe, have established as matter of fact the exclusive exercise of rights of fishing in any locality, and have maintained it against others in the old days, that is before British law was established in the Island, then we have given a title to those rights as an easement. We have never recognised any rights below the surface, but simply an easement, and the easement in this case I suppose would be the right to use the surface of the soil and all above it, but nothing below it, and excluding others from interfering with those rights... I do not remember that I have ever had a case below low water mark, although I think it is quite possible that such exist. I remember there is a rock to the North of Waiheke which is a great fishing ground for whapuka [sic], and I am aware that the Ngatipaoa defended that ground against attacks from the North. I cannot say that the Court has decided that case, or that it has decided any such...

Sir William Fox Would you apply that doctrine to the sea beach as well as to a tidal river or mud-flat? I do not think I would, but I should not say so decidedly.

Have you ever done so? - No, I have not. There is a valuable shell fishery on the West Coast between Hokianga and Kaipara called Toheroa, where the natives obtain a large clam. That

75 Petition of Mahurehure Tribe, LE 1/1880/6, National Archives. Cited in T Walzl, WAI 27, Z-49, 89. 
fishery is of great value to them, but whether they have exercised rights of property to the exclusion of others I do not know, but that is the essence of their title to my judgment. They must prove exclusive use.

Several weeks later the Committee investigated a complaint that a fishery right awarded as an easement by Fenton to Ngai Tahu in 1868 had been impaired by drainage. Fenton appeared again and explained that in his view the injury to these fisheries was wrongful. He thought that the drainage should give rise to compensation or a remedy at law. ${ }^{76}$

These later statements suggest a number of points. In order for the Court to award rights in the foreshore some tangible act of appropriation must be proved. Fenton insisted that the test was exclusive use, implying that casual or "public" use of an area would not be sufficient. ${ }^{77}$ This approach finds parallels in the distinction that Maori in the nineteenth century often drew between the exercise of a right and the performance of an activity that had no proprietary significanc. Certain beaches might thus be regarded as a common highway. ${ }^{78}$ Material on a beach that had no recognised value might not be subject to claim by any particular party. Thomas Chapman, of the Church Missionary Society recorded in 1852 that two rival chiefs had laid claim to a reef of rock lying off a river mouth because they sought "the distinctive merit" of supplying stones from it for a church. "All parties are surprised", he wrote, "because such a thing as claiming loose stones on the beach was never before heard of."179

The taking of pipis was often portrayed by Maori as an act of little consequence, either because the resource was so abundant in some places or the gatherers were mere transients. It might be tolerated by the real owners of a location without compromising their claims to the land. Examples from around the North Island might be given, although one need not look beyond the Kauwaeranga evidence for illustration. "As to pipis", explained Taipari, "... it was a general rule in former times that any one could consume them.... All strangers were allowed to gather pipis in former days..." ${ }^{10}$ In

76 Petition of Te Oti Pita Mutu and others, LE 1/1880/6, National Archives. Cited in Walzl, above n 75.

77 This standard was applied by the Maori Appellate Court in the later case of Ngakororo 12 Auckland NAC Minute Book 137.

78 For example, Native Land Court, Maketu Minute Book 2, pp 285, 288. E Stokes A History of Tauranga County, (Dunmore, Palmerston North, 1980) 124. William Yate Journal, 9 January 1834, MS 1833-45, Alexander Turnbull Library.

79 Thomas Chapman Journal, 16 February 1852, Alexander Turnbull Library.

80 Native Land Court, Hauraki Minute Book 4 218, 220. 
Whakaharatau, Te Wahapu testified: "We use the adjoining lands for fishing purposes with Ngati Whanaunga and Ngati Maru's. We did not suffer persons to use nets on that land, but allowed them to gather pipis." 81

At the other end of the scale, such acts as the imposition of rahui, the naming of a shellfish bed, the staking of nets, or the taking of waterbirds were unequivocal marks of ownership. ${ }^{82}$ Fenton's requirement of exclusive use therefore had some parallels in custom, and cannot be easily dismissed as an application of Dr Arnold's doctrines to marine property. The practical result of Fenton's test was that court would not recognise Maori rights as being co-extensive with the entire coastline, but rights would be protected if a suitable act of ownership was established.

Fenton's evidence in 1880 suggests that he was unaware of the effect that would later be attributed to section 147 of the Harbours Act 1878. This section prohibited any grant of the foreshore except by special act. The Court of Appeal held in Ninety-Mile Beach that this removed the power of the Native Land Court to investigate title or issue a freehold title below high water mark. Fenton's successor, J E MacDonald was also oblivious to this change, having awarded rights to the Porirua foreshore in 1883. Given the Court's willingness to apply the Kauwaeranga principle after 1878, the Harbours Act was unlikely to pose a practical deterrent to further foreshore claims in the nineteenth century and cannot explain the small number of such claims after Kauwaeranga. There might also have been room for doubt that the kind of right awarded by the Court was a grant, disposition or conveyance of the foreshore in terms of the section. ${ }^{83}$

\section{SHOULD FENTON HAVE AWARDED A FEE SIMPLE TITLE?}

Fenton has been criticised for awarding a right of fishery rather than the fee simple in the foreshore. It has been said that the result in Kauwaeranga was a retreat from the reasoning in Whakaharatau and the earlier practice of the Court (an argument dealt with above) and was dictated by considerations of policy or politics. According to the

81 Native Land Court, Hauraki Minute Book 4192.

82 For further discussion of these issues see evidence of F Sinclair, WAI 167, C-10, 39-46, and A Ballara "The Origins of Ngati Kahungunu", PhD thesis, Victoria University of Wellington 1991, 347.

83 The assumption that the Court's jurisdiction was entirely removed in 1878 was later to deprive Ngati Toa of the protection which the 1883 Porirua decision might otherwise have provided. In the twentieth century, their objection to the reclamation of the Porirua mudflat was ignored on the ground that the 1883 award was ultra vires. LE 1/1960/12, National Archives. 
Muriwhenua Fishing Report: "The convenience of the Kauwaeranga Judgment was that it protected the Crown's interest in gold, which was the main concern at the time." ${ }^{18}$

Several earlier events appear to have shaped Fenton's attitude to the Thames applications. While Resident Magistrate in Kaipara in 1855, Fenton had been asked to settle a dispute about toheroas. The fishery in question had many years earlier been a cause of conflict between Ngati Whatua and Ngapuhi, with the "undisputed possession" ultimately being yielded to the former. The issue had arisen again because large quantities of toheroa were being taken for consumption by European station hands. Fenton advised that: ${ }^{85}$

[t]he Ngatiwhatua have made a demand for annual payment by way of rent - The Europeans, supported by Ngapuhi, aver that the fishery, being below high water mark of the ocean, is the property of the Crown; and after various discussions amongst themselves the matter has been left to my decision. I confess myself unwilling to decide the question without reference to high authority though I am inclined to think that the Treaty of Waitangi would confirm the Ngatiwhatua in the enjoyment of a right, which they seem for many years previous to the establishment of British sovereignty to have exercised uncontested.

There is, in this tentative response, a hint of the Kauwaeranga finding that the Treaty would oblige recognition of an exclusive right of fishery, though Fenton still seemed undecided about rights to toheroa in his 1880 evidence.

Nearer in time to Kauwaeranga, in 1868 Fenton had awarded fishing "easements" over areas of Crown land within the Kemp purchase in the South Island. ${ }^{86}$ This shows he had already applied the idea of an exclusive right that did not depend on ownership of the underlying soil. Fenton was also prepared to admit a public right of way over the areas covered by the easements, which again finds a parallel in Kauwaeranga. In 1868 he had also sat on the Orakei case, and heard considerable evidence about the significance of shark fisheries for claims to land. This background may well have prompted Fenton's questions about shark fisheries during the Kauwaeranga case. There was an indication in 1869 that Fenton already thought that, while the Maori claim to ownership of the

84 Muriwhenua Fishing Report para 5.4.5. New Zealand Law Commission Preliminary Paper No 9: The Treaty of Waitangi and Maori Fisheries (1989) 16. A Crown grant of the foreshore would not affect the Crown's claims to gold in any case.

85 IA 1 1855/202, National Archives. Cited in Law Commission Preliminary Paper No 9 "The Treaty of Waitangi and Maori Fisheries" 145.

86 A Mackay "A Compendium of Official Documents Relative to Native Affairs in the South Island" vol 2, 210-216. His jurisdiction to do so was conferred by an Order of Reference under the Native Lands Act 1867. See the Ngai Tahu Reference Validation Act 1868. 
foreshore was doubtful, "the fishery right undoubtedly did exist." ${ }^{187}$ We know also from his own statements in the Legislative Council that he believed gold on Maori or private land remained vested in the Crown. ${ }^{88}$

Some of these strands were woven into the Kauwaeranga decision. Certain key elements - the Treaty protection of fisheries and the translation of such rights into an easement or exclusive right of fishery - already formed part of the Chief Judge's thinking before he was called upon to decide a case involving auriferous foreshore land.

The Native Land Court regularly decided claims to terra firma on the basis of hunting and gathering rights exercised on the land. If such rights translated to a fee simple interest in dry land, why was the act of fishing held to warrant a lesser interest in the foreshore? Fenton confessed his uncertainty about the interest he should award, and expected that the question would be decided by the Supreme Court or Parliament. He considered that the distinction lay in the separate mention of fisheries in the Treaty. The Native Lands Act required him to decide the "right title estate or interest" of claimants "to or in the land" before him, but he doubted that he would have jurisdiction over land beneath the sea were it not for the specific guarantee of fisheries. The fact that fisheries were separately mentioned suggested to Fenton that such rights were of a different quality from rights to dry land. This, together with the public interests involved, led him to hold that the fishery right should be upheld but not the claim to fee simple.

The Chief Judge thus followed a middling course. The fisheries guarantee encouraged him to think that he had jurisdiction below high water mark - and, indeed, to contemplate a jurisdiction below low water mark. But he held that the apparent distinction between lands and fisheries meant that these could not be regarded in the same light. Kauwaeranga therefore represents a middle position between the view that "land" in the Native Lands Act did not mean land covered by the sea, and the view that the Court had jurisdiction to award full title above and below high water mark. The more conservative position, that "land" meant "lands in the ordinary acceptation of the word", is one that the terms of the Act might easily have supported. ${ }^{89}$ Guided by

87 See statement by F D Bell, (1 Sept 1869) 6 NZPD 905.

89 The phrase is J C MacCormick's. He remained privately opposed to the Court exercising any jurisdiction over fisheries and foreshores._McCormick thought that it was never "the intention of the Legislature in creating Native Land Courts to give them jurisdiction to entertain such applications. Both the history of the legislation relating to native lands and the general scope of the Native Land Acts... point to a different conclusion."_Daily Southern Cross, 18 April 1872. See also MacCormick to Fenton, 16 August 1871, [1871] AJHR A-2A, 21. The overall philosophy of the first Native Lands Acts - the conversion of Maori proprietary customs to titles derived from the 
wording of the Treaty, Fenton was persuaded to go further, but not to the extent of exercising the Court's ordinary jurisdiction below high water. He acknowledged the maxim that "the honour of the King is to be preferred to his profit", but thought: 90

there can be no failure of justice if the natives have secured to them the full, exclusive, and undisturbed possession of all the rights and privileges over the locus in quo which they or their ancestors have ever exercised...

Whatever opinion one forms of this reasoning, it is hard to see that Kauwaeranga resulted in much "convenience" to the Crown or made any practical difference to events at the Thames. The Crown was committed by its own policy and the Gold Fields Act to treat with Maori before opening the Thames foreshore to mining. Because fisheries easements were intended to have legal protection from interference, the Kauwaeranga awards would themselves have been a bar to mining before Maori claims had been satisfied. The sums offered by the government to cancel those claims were not reduced by the Court's decision. By the standards of the time, the amount finally paid was high, especially when compared with ordinary purchases of land in the district. ${ }^{91}$

\section{THE RELATIONSHIP BETWEEN LAND AND FORESHORE RIGHTS}

An important question arising from the debate over the Thames and Coromandel claims is the reasonableness of holding that exclusive Maori rights in the foreshore depended on Maori maintaining possession of the adjoining land. A full study of this matter would be a lengthy task, but it may be helpful to sample the kind of evidence that would need to be considered.

The sources speak of an intimate connection between ownership of land and rights exercised, or acts done, along the coastline. Points in the sea were sometimes included in the recitation of rohe. Guns, boulders, or even a child cast into the water might be offered as a proof of who owned the land. ${ }^{92}$ At Hokianga, the blood of a chief was

Crown (or assimilated as nearly as possible to ownership of land according to British law) - might also have justified the conservative position.

90 A Frame "Kauwaeranga Judgment" (1984) 14 VUWLR 227, 245.

91 It is true that much larger sums were soon invested - or perhaps risked - in mining the mudflat. Large-scale investment and, in some instances, large profits were also a feature of mining on the land nearby. As Maori were not actively engaged in this kind of mining, the real issue is not the awards of the Court but the appropriateness of the Crown exercising pre-emptive control over auriferous land. (E W Puckey defended the payment of $£ 1,500$ to Rapana by observing that $£ 50,000$ had been spent on developing this part of the beach. Puckey to Colonial Secretary, 22 May 1873, AP 2/21, National Archives.)

92 For example, Native Land Court, Northern Minute Book 2, 90; Waiapu Minute Book 7, 301; Gisborne Minute Book 1, 223. 
dispersed in the water "for the express purpose of claiming the land - a Maori custom". 93 The erection of rahui and the claiming of stranded whales were powerful symbols of ownership. ${ }^{94}$ So too was the assertion of a right of fishery. The case of Waihi No 6, involving land in the Maketu estuary, illustrates the point. A portion of the claim was disputed on the grounds that other parties had taken pipis there and made use of certain gravel pits. But the claimants could show strong acts of ownership. Their chief, Winiata, had established a rahui to control the taking of birds, and they had staked their nets in the river over a lengthy period: ${ }^{95}$

According to Maori custom kirikiri [gravel] is common property... Winiata had taro growing there[,] he would not object to any one getting kirikiri on his land. If a person was to stake nets on another persons land the owner of the land would probably destroy them or send them away. If Winiata had been a stranger and placed his stakes there it would amount to taking possession of the land. Winiata asserts his right to this south end in consequence of his setting up his Rahui and staking his nets.

Unlike the taking of pipis or gravel, the erection of fishing stakes signified a proprietary claim. The reasoning advanced here is that if Winiata had not been the owner of the adjoining land, he would have been opposed. As he had not been, the land must be his - the implication being that the owner of such rights to the foreshore and the owner of the land must be the same party. A similar view was expressed by Hori Ngatai at Tauranga in 1885 . He told the Native Minister: ${ }^{96}$

... with regard to the land below high water mark immediately in front of where I live, I consider that that is part and parcel of my own land... I will look upon the land below high water mark as being part of my own garden.

Ownership of land conferred privileges that bear analogy with riparian rights. In 1874, in a protest against the granting of a timber-floating licence in the Kauwaeranga Stream, Hotoreni Taipari remarked: ${ }^{97}$

No payment was made to us for logs that lodged on our land in the year 1873 - according to Maori custom if fish or canoes or totara or kauri timber lodged on any person's land that would be his property, this was the custom all over the island, and although those things might be the property of a very great chief he would not get them again.

93 Native Land Court, Northern Minute Book 4, 151.

94 For example, Native Land Court, Gisborne Minute Book 4, 136; Napier Minute Book 13, 292.

96 [1885] AJHR G-1, 60. Emphasis added.

97 AP 2/22/3512, National Archives. 
In conformity with this principle, Maori had demanded money for sawn kauri that had drifted onto the Thames mudflats in 1868. ${ }^{98}$ Taipari's assertion about the widespread observance of this custom is borne out by the experience of missionaries in the far north of the country. ${ }^{99}$ There is a suggestion that the same rule governed the allocation, as between owners of opposite banks, of stranded timber on the Tarawera River. ${ }^{100}$

The geographical association of aquatic and terrestrial property rights should not be thought of as a strict correlation. In a hunting and gathering economy, which emphasised the ownership of particular resources, a rigid definition of territory was often unnecessary. It was not until the advent of the land sale that the translation of such rights into ownership of defined boundaries became imperative. ${ }^{101}$ Nevertheless, it seems to have been exceptional for exclusive rights in the foreshore to be held by parties other than those who possessed the adjoining land. The natural assumption was that any such rights ran with the land (or were a proof of ownership of the land).

Did the circumstances of land sales encourage Maori to think that this assumption would not apply? There is some evidence that the effect of sales on foreshore rights had been considered even before annexation. The missionary, A N Brown, was told by two Maori in 1839 that when the Te Papa station had been bought the year before "...a cockle-bed in front of our settlement was not included, and that our Natives should no longer fetch shell-fish from thence unless they were paid for them." ${ }^{102}$ This incident was one of a number of petty annoyances at this time - part of the station was being planted in potatoes to test how the missionaries would react, and some people alleged that they had been cheated out of payment by their friends. Such behaviour was common when missions were established in areas that had little previous exposure to Europeans. A period of testing was typical, and further payments would be sought on a range of pretexts. Brown evidently saw the demands in this light and was "almost certain

98 [1869] AJHR F-7, 15.

99 Nathaniel Turner, in reporting the fate of the "Mercury", noted that the vessel was "driven with her stern on shore. And according to New Zealand custom she became the lawful prize of the chief or party on whose coast she had grounded." Turner Journal, qMS-2062, 106, Alexander Turnbull Library. For a further illustration of the principle see John Hobbes Journal, 13 December 1840, MS 612, Alexander Turnbull Library.

100 Native Land Court, Whakatane Minute Book 1, 217.

101 On occasions, the Native Land Court made provision for the overlapping of rights to the coastline. See, for example, the Awapuni decision, Important Judgments Delivered in the Compensation Court and Native Land Court 1866-79, (Auckland, 1879) 147. For a similar result involving a freshwater fishery, see Native Land Court, Northern Minute Book 10, decision in Omapere No 3, 226.

102 A N Brown journal, 20 August 1839, Micro MS Coll 4, CN/M11, 517-518, Alexander Turnbull Library. For further discussion of such incidents see F Sinclair, WAI 45, I-3. 
that in these squabbles the Natives will ultimately give up their unreasonable demands, after a long waste of time and giving them some trifling." 103

Brown's experience at Tauranga suggests that foreshore rights might well be an issue as the parties came to terms with the implications of sale. In districts with a longer history of contact, the kind of annoyances suffered by Brown had become rare. In the Bay of Islands, where land sales had been extensive, the physical problem of gaining access to the coastline was already becoming apparent. The CMS missionaries felt obliged to purchase an area along the Kerikeri River and place it in trust for Maori, "as it is the last part of the river which is not sold where shell fish can be procured."104 Nearer Waitangi, Ngati Rahiri apparently lacked a place to live - as of right - while they fished and took pipis, until Henry Williams made over land at Te Ti by deed of gift in 1839. ${ }^{105}$ These examples may not shed much light on the narrow issue of whether sales were thought to affect the foreshore, but they do suggest that sales posed a practical impediment to enjoyment of the coastline, even at this early date.

The concern to reserve aquatic rights, or at least the right of access, was a feature of some sales after annexation. In 1853, McLean encountered resistance to his purchase of land in the Wairarapa until the vendors were assured that the sale would not prejudice their right to the eel fisheries in Lake Wairarapa. ${ }^{106}$ Other purchases of this time, such as the Ahuriri and Wanganui transactions, expressly stipulated that certain rights of access or fishery remained. The Ahuriri deed contained a clause reserving to Maori "an equal right" to fish, shellfish and other productions of the sea, together with a right to land canoes at places to be specified. This had been inserted to allay the fear of Tareha and other chiefs that they might eventually be deprived of these rights. Ten years later, Tareha said that he had sold only to high water mark and therefore owned land that was being reclaimed from Ahuriri lagoon. ${ }^{107}$ Apparently he did not pursue the matter. ${ }^{108}$ The purchase in 1853 of islands in the Papakura Creek (Manukau) was expressly limited to

103 Above n 102, 518

104 R Davis journal, 7 August 1839, Micro MS Coll 4, CN/M11, 31, Alexander Turnbull Library.

105 See evidence of John Williams, Native Land Court, Northern Minute Book 10, 165-166, 356ff and judgments at Northern Minute Book 10, p 170, and Northern Minute Book 11, 35. For pipi gathering contrasted with shark fishing, see evidence of Hori Wihana, Northern Minute Book 11, 17.

106 [1891] AJHR session 2, G-4, 3, 24.

107 Te Whanganui a Orotu Report, 92.

108 This incident bears comparison with Tareha's claim to gravel in the Meanee River. He appears to have let this claim drop as well. J L Lambton Carter to McLean, 29 November 1862, MS 32, Alexander Turnbull Library. Hawke's Bay Times, 4 December 1862. 
high water mark. The exclusion was evidently thought unusual; the Surveyor-General noted on the deed that "[t]he natives insisted on this being specified, intending thereby to retain the right of putting down the stakes for their nets when fishing."109

The language of alienation at this time supports the view that, in general, the sea was not traditionally regarded as property. The image of sending the land sold out to sea was sometimes used to express the act of transfer. An illustration of this occurred during the purchase of Ngati Awa interests in the northern South Island in 1856. McLean reported that one of the principal chiefs, Ropoama Te One, had expressed the finality of the alienation in various ways, including "their usual metaphor", namely: "...we have for ever launched this land into the sea."110 Further examples can be found in discussions of land-selling in Taranaki. ${ }^{111}$ This metaphor would make little sense if coastal boundaries were regarded as dividing the terrestrial property being conveyed from marine property that was being retained. ${ }^{112}$

Maori behaviour after land sales also suggests an appreciation that aquatic rights were affected by these transactions. Where rivers formed a boundary between Maori and European land, disputes occasionally arose over fishing or the right to stranded timber. On at least two occasions McLean resolved such disagreements by advocating a division of interests according to ownership of the banks - a rough-and-ready application of the ad medium filum principle. ${ }^{113}$ Maori appear to have been satisfied with this solution. As suggested above, it would seem to have conformed with the division of rights under the customary regime. It further indicates an acceptance that sales implied some transfer of aquatic rights to the new owner, even if these had not been expressly stipulated in the deeds.

This is reflected in the nature of claims that Maori would later bring to the foreshore. An example is Kawana Paipai's claim to part of the bed and foreshore of the Wanganui River. Kawana was a very old chief, said to be "learned in Maori traditions and

109 "Islands in Papakura Creek", 15 June 1853, Deed Number 266, Turton's Deeds, Manukau District, 323.

110 McLean to the Colonial Secretary, 7 April 1856, [1862] AJHR C-1, 366.

111 See L F Head "Maori Land Boundaries" WAI 167, A-23, 53-57.

112 A similar figure of speech might be used to express loss in other contexts. For instance, Rapana wrote in 1869: "The miners' rights matter is all wrong. It has fallen into the sea. We have been searching for it, but have not found it." The implication here was that the issue had been lost sight of, or that what was happening no longer made sense to the Maori at Hauraki. New Zealand Herald, 24 July 1869, 5.

113 See evidence of F Sinclair, WAI 167, C-10, 25-30. These incidents occurred on the Wanganui and Waikare Rivers. 
history". 114 Harbour works on the European side of the tidal reaches had apparently caused the river to erode part of his sections in the Putiki Reserve. In 1871 he brought a claim that included one of his sections - Ngongohau No 1 - and the adjacent bed and foreshore out to the middle of the river. Other leading figures included some smaller portions of foreshore in their applications. The Court ordered the river bed to be excluded. Undeterred, Kawana brought a similar application for some other sections in 1873. Although his map showed a claim to the middle of the river, he confined himself to asking for the foreshore only. In the course of evidence, his son, Hori Kerei, alluded to the distinction, noted earlier, between the proprietary rights of the owner and "public" uses: 115

[The land] has been cultivated by Kawana in the past but is now covered by water - the canoes of the iwi pass over - the beach is travelled over by everybody - all have a right - if there were pipis there my father only would have a right to them - he has refused to allow them to be taken from there.

This application met the same fate as the first. But the river bed claim is notable because of its obvious link with Kawana's ownership of the dry ground. There was no suggestion that it symbolised a claim to the whole river, nor was there any hint of an overriding "tribal" right that conflicted with Kawana's private claim. In the circumstances, his application implied that the other Putiki owners might make a similar argument, while the bed beyond the mid point had passed to the government by virtue of the Wanganui sale in 1848.

Some other foreshore claims were likewise tailored to possession of land. As a result of the 1855 earthquake, parts of the shoreline of Wellington Harbour were elevated and became dry land, including a considerable area in front of Pipitea Pa. Ihaia Porutu laid claim to this ground in 1866 and it was apparently still the intention of the Pipitea people to assert ownership in 1867, when the pa was surveyed for a Land Court hearing. But there was no general claim to the bed of the harbour at this time and nothing was said of other parts of the foreshore which had been reclaimed or become dry. ${ }^{116}$ Similarly, the Porirua foreshore claim in 1880 corresponded to an area reserved in 1847. It was not a claim to all the mudflats in the harbour.

114 The Yeoman, 13 June 1884, 5.

115 Native Land Court, Evidence of Hori Kerei Paipai, Ngongohau No 7, Wanganui Minute Book 1E, 661. A copy of the plan is annexed to WAI 167, C-10.

116 MA 1/1866/409, 358, National Archives; Plan Number WD3140, LINZ, Wellington. MA1/1866/409 National Archives. 
The Riverton foreshore claim in 1874 was limited to land opposite a reserve. Mackay noted in 1891 that Ngai Tahu sought the "sole right to fish along the sea frontage of their reserves where such lands abut the coast". 117 H K Taiaroa's claim to the Mangahoe inlet on Otago Peninsula was consistent with this approach. In 1877 he asked a question in the House concerning rights to this body of water. Taiaroa noted that it was "situated in the midst of his land. The lands adjacent to the place had all been granted." He objected to Europeans plundering the oysters and fish and wished the Government to put a stop to this "until the Native title has been extinguished." The Ngai Tahu Sea Fisheries Report commented that Taiaroa "appeared to accept... that while a stop should be put to the practice until the Native title was extinguished the Europeans might be able to resume fishing thereafter."118 The Coromandel claim in 1872 was thus unusual in including foreshore opposite European or Crown land, although it appears to have begun with claims to mudflats adjoining customary land.

Two of the early petitions concerning the foreshore also admit a link between land ownership and foreshore rights. Hoepa Mataitaua, of Te Kouma on the Coromandel Peninsula, protested in 1882 about the taking of oysters and shellfish by people from Australia and elsewhere. He requested a law "to give the right of fishing on foreshores to the owners of the land abutting upon them."119 More explicitly, Hone Peti and six others complained in 1884 about the taking of oysters at the mouth of the Mangonui River. They added that they "do not want oysters, \&c., growing on the foreshore of Government lands; they merely wish what they are entitled to to be kept for themselves."120

In general, it seems that foreshore rights were not frequently discussed in the negotiation of the early coastal blocks. If concerns about continued use had been raised, it may be that they were allayed by assurances about the public right of access and deemed unworthy of particular mention by the land purchase agents. Towards the end of the century, modification of the coastline by harbour boards and increasing exploitation of shellfish resources, especially oysters, were starting to cause unease. These anxieties were voiced in speeches made to the Orakei parliament in 1879. Some spoke in broad or even confused terms about the Treaty guarantee of fisheries, or complained that anchorage fees were not paid to them. Apihai Te Kawau said that he had only given land, not the sea: "...therefore the sea belongs to me. Some of my goods are there. I consider

117 [1891] AJHR G-7A, 7. Cited in evidence of D Armstrong, WAI 27, M-17.

118 Ngai Tahu Sea Fisheries Report, 168. For Taiaroa's application see Native Land Court, South Island Minute Book 1B, 232, 15 September 1883.

119 [1881] AJHR I-2, 27-28.

120 [1884] AJHR session II, I-2, 16. 
the pipis and the fish are my goods."121 Other chiefs were content to have protection of fisheries that abutted the land they retained. Herewini Mauwi declared that his mana remained upon his land (some 7,000 acres) "because this land has not yet been surveyed.... Let me have the mana over that land alone; also, over the fisheries and pipigrounds therein."122

These grievances were still alive when the third session of the Orakei parliament was held in 1881. The New Zealand Herald reported that "the Maoris have been very much annoyed by finding that the whole of the foreshore of Auckland harbour, even that opposite native land, has been conferred on the Harbour Board."123 In his opening address, Paora Tuhaere stated that "the government had not adhered strictly to the Treaty by taking away the foreshore from native lands abutting on the sea..."124 There was further discussion on the foreshore question the next day: ${ }^{125}$

With regard to the question of the fisheries and pipi banks, there was some debate, but a letter was read, showing that Judge Fenton would now settle that question.

It is not known what steps Fenton was expected to take. If he made any proposal it is likely to have followed the principle laid down in Kauwaeranga and reiterated before the Native Affairs Committee two years earlier.

About the same time as the third and final parliament at Orakei, there was a large hui at Waitangi at which foreshore rights were again raised. The reports of the speeches contain little detail. Wi Katene, sometime MHR for Northern Maori, demanded: "Give us the seabed. Let us reap the benefit of all fisheries according to the Treaty." The Native Minister replied with these words: ${ }^{126}$

As to the foreshores and fisheries, I have heard a great deal about them, but do not quite understand what you are wanting. The law of nations is that the great highway of nature, the foreshore, is reserved for the use of the whole, not individuals only. Without a special vote of Parliament the foreshore belongs to the sovereignty for the use of both nations.

121 [1879] AJHR G-8, 29.

122 Above n 121, 20.

123 New Zealand Herald, 12 March 1881. Emphasis added.

124 New Zealand Herald, 21 March 1881. Emphasis added. The foreshore opposite Ngati Whatua land at Orakei had been excluded from the Auckland Harbour Board endowment grant in 1869. See [1869] AJHR F-7, 6; AAFV 997/A45, National Archives.

125 New Zealand Herald, 22 March 1881.

126 New Zealand Herald, 25 March 1881. 
Wi Katene clarified his request: ${ }^{127}$

Re pipi beds and fisheries, these were lost sight of. I understand you to say the Crown takes the foreshore in trust for the people. That is right in respect of, say, Russell, but our pipi beds are our own. Should a town spring up here, what about our pipi beds?

So far as one can tell, Katene believed that, while some pipi beds were undoubtedly retained by Maori, those in some localities were no longer their exclusive property. Where Europeans had bought land and settled, the foreshore was apparently regarded as public domain. His concern was that if settlement spread closer to Maori land, there would be no means of protecting what he thought was rightfully their own.

In 1886, Katene adopted a different stance in a petition claiming ownership of reclaimed land in Auckland and Wellington. He contended that the pipi beds affected by these works "were not sold by them with the dry land adjoining". The Native Affairs Committee did not support the petition, observing that "no proof of such exemption from any sale has been adduced."128 A more numerously signed petition on the subject of reclamations met with a recommendation that the government should institute an inquiry into Maori rights to coastal fisheries. ${ }^{129}$

A deeper study of context would be required before one could confidently draw conclusions from the material sampled here. The evidence reviewed does not tend entirely in one direction, but the general pattern supports the view that sales of land were understood to affect any exclusive rights in the foreshore. This is broadly in line with the tentative conclusion of the Muriwhenua Fishing Report that fisheries associated with foreshores are "patently connected to the land", and might be affected by land sales. ${ }^{130}$

\section{IS KAUWAERANGA A RECOGNITION OF "NON-TERRITORIAL ABORIGINAL TITLE" IN NEW ZEALAND?}

In his 1984 article on Maori fishing rights, Paul McHugh contended that Kauwaeranga acknowledged the existence, under the Native Lands Act, of a "vital distinction ... between territorial and non-territorial aboriginal title". ${ }^{131}$ "Territorial aboriginal title" was likened to a right of ownership, or exclusive use and occupation - something akin to the

127 New Zealand Herald, 25 March 1881

128 JLC, 1886, xii; 102.

129 [1886] AJHR I-2, 28.

130 Muriwhenua Fishing Report 207-208.

131 P G McHugh "The Legal Status of Maori Fishing Rights in Tidal Waters" (1984) 14 VUWLR 247, 258 
notion of freehold. "Non-territorial aboriginal title" comprised "rights of a lesser character which do not amount to a claim to exclusive 'ownership' but subsist by way of a charge upon the land."132

Building on this distinction, McHugh argued in later publications that the extinction of native title in New Zealand, by purchase or under the Native Land Acts, might have only affected the "territorial" component of that title, leaving "non-territorial" rights extant and cognisable at common law. ${ }^{133}$ A modern court could examine some historical purchase to see if "non-territorial" elements of the native title had not been expressly extinguished. ${ }^{134}$ Titles created under the Native Land legislation, especially after 1909, only affected the "territorial title" and will also leave "non-territorial" rights that may be recognised by a court. It is said that the people entitled to the benefit of such rights are likely to be a wider class than the owners of the "territorial" title. ${ }^{135}$ Any "non-territorial" rights that survive through the partial extinguishment of native title may exist as a burden over various categories of land, particularly Crown land. ${ }^{136}$

The notion that native title was so divisible has proved influential. Williamson J, drawing on the McHugh articles, held in Te Weehi that the protection of "any Maori fishing right" in section 88(2) of the Fisheries Act included the non-exclusive, nonterritorial right that the appellant claimed to be exercising. ${ }^{137}$ Earlier cases were distinguished on the grounds that they concerned claims to territorial title or exclusive rights. It is not clear that Te Weehi concerned what is, strictly speaking, the foreshore. The language of the judgment and the fact that Mr Te Weehi was charged with taking paua suggests that it did not. But the decision may imply a finding that the extinction of any native title to the ground on which the fishing occurred did not capture the "nonterritorial" right to fish. The decision is not explicit on this point.

An acceptance of partial extinguishment is, however, more apparent in the later case of Taranaki Fish $\mathcal{E}$ Game Council $v$ McRitchie. ${ }^{138}$ This case involved the taking of trout without a licence in an area where native title had evidently been extinguished. The

132 Above $\mathrm{n} 131,256$

133 P G McHugh "Aboriginal Servitudes and the Land Transfer Act 1952" (1986) 16 VUWLR 313, 324

134 Above $\mathrm{n} 133,326$

135 Above $\mathrm{n} 133,325$.

136 P G McHugh "The Legal Basis for Maori Claims against the Crown" (1988) 18 VUWLR 1, 12

137 Te Weehi v Regional Fisheries Officer [1986] 1 NZLR 680, 692.

138 [1997] DCR 446. The decision has since been overturned by the High Court and the case has been taken on appeal to the Court of Appeal. 
alleged customary right to do so was held to be a Treaty or aboriginal right - the distinction was not seen as important - which was preserved by section $26 \mathrm{ZH}$ of the Conservation Act 1987. This result strongly implies that the right confirmed by the Court survived the extinction of native title to the land on which it was exercised.

Can Kauwaeranga be seen as a precedent for this development of the common law? At most, the decision establishes that a right of fishery may, in special circumstances, coexist with Crown ownership of the underlying land. Fenton's Kaitorete judgment stands for the same proposition, although the Court's jurisdiction in that case was limited to a question referred by the Governor under a statutory provision.

But the crucial aspect of Kauwaeranga is how the blending of Maori rights with Crown ownership was accomplished. This was manifestly not the outcome of a partial extinguishment of the full "territorial" title, because the applicants were never awarded so great an interest. In the eyes of the Court, the right to receive a fee simple title did not extend to the foreshore and a fishing right was awarded instead. No question of partial extinguishment could arise because there was no "territorial title" to become separated from the fishing right. Thus, Kauwaeranga is not authority for the idea that native title was generally divisible into "territorial" and "non-territorial" components, which must both be expressly extinguished in order to free a piece of land from aboriginal rights.

The "non-territorial" character of the rights awarded in Kauwaeranga should not be exaggerated. Those rights were "territorial" in the sense that possession of the adjoining land appears to have been a pre-requisite. This feature may have been overlooked by Cooke $\mathrm{P}$ in his observations on the case in the Muriwhenua fisheries case. ${ }^{139}$ Rights to the Kauwaeranga mudflat were certainly apportioned according to ownership of the land and there is no clear evidence of the Court awarding similar rights where Maori did not possess the adjoining land. The indications are that native title would not be found in such cases.

The Kauwaeranga rights were, moreover, exclusive. They do not bear analogy to the kind of "non-exclusive right" found in Te Weehi or McRitchie. A "non-exclusive right" of this nature would not have been recognised by the Native Land Court in the nineteenth century, and there are suggestions in the evidence that such activity would not signify a "right" under the customary regime. If non-exclusive rights had also to be expressly identified and extinguished to clear a parcel of land from Maori claims, the consequences

139 Te Runanga o Muriwhenua Inc v Attorney-General [1990] 2 NZLR 641, 655. "The survival of fishing rights though land titles have been extinguished was recognised even as to the foreshore by Chief Judge Fenton in his Kauwaeranga Judgment of 1870..." Lord Cooke is, of course, correct in the sense that the issuing of titles to the adjoining land extinguished customary ownership, but he seemed to have in mind the transfer of ownership. 
at the Thames would have been rather strange. Having paid large sums to extinguish the exclusive rights of fishing identified by the Native Land Court, the Crown would have the further task of buying out the non-exclusive rights which, supposedly, still burdened the mudflats and formed, in effect, a bar to mining. On McHugh's analysis, the holders of the latter rights might well be different people from those who had been paid for their exclusive rights. ${ }^{140}$ This hypothesis is hard to reconcile with section 48 of the Native Lands Act 1865. That section provides that a Crown grant based upon a purchase from the certified Maori owners "shall bar all estates rights titles and interests of all persons whomsoever therein except the grantees named therein..." This wording does not suggest that the statute "recognised" that a lesser form of native title survived such a grant and could be vested in persons other than the certified former owners. ${ }^{141}$ It is just as unlikely that such interests survived the issue of a certificate or grant to those former owners.

McHugh argues that the complete extinguishment of both territorial and nonterritorial title could only be accomplished by a purchase that specified all "incidents" of the original native title, or by a Land Court order that included a "comprehensive enumeration of the traditional incidents". ${ }^{142}$ There is a curious artificiality about this requirement. It would perhaps be reasonable if the divisibility of native title was something that was indeed recognised at the time and for which provision could be made.

But the colonisation of New Zealand proceeded upon different assumptions. With the early abandonment of any prerogative claim to waste lands, there could be no question that native title ran over the vast areas that remained unpurchased. The colony could only expand through the progressive extinction of that title by, among other means, Crown purchases and the conversion of customary ownership under the Native Lands Acts. These processes envisaged a native title that was not composite. For the most part, it was supposed that native title either existed in full or was extinguished. If it was found in some attenuated form, this was because a native right had been expressly reserved from sale (as Kaitorete demonstrates) or because native title was deemed not to have existed in its fullest form. ${ }^{143}$ Kauwaeranga encapsulates the latter possibility and nothing more.

140 P G McHugh "Aboriginal Servitudes and the Land Transfer Act 1952" (1986) 16 VUWLR 313, 325.

141 P G McHugh "The Legal Status of Maori Fishing Rights in Tidal Waters" (1984) 14 VUWLR 247, 258.

142 Above n 140, 324.

143 The definition of "easements" by Fenton in the aftermath of Kaitorete was followed by the enactment of the Ngaitahu Reference Validation Act 1868. Section 2 provided that the orders of 
The Native Land legislation warrants further examination from this perspective. As the terms of the first Acts make plain, the legislative intention was to transform native title into a new and more precise form of ownership. The preambles speak of encouraging "the extinction of [Maori] proprietary customs and [providing] for the conversion of such modes of ownership into titles derived from the Crown" (the 1865 Act) or the assimilation of these customs "as nearly as possible to the ownership of land according to British law" (the 1862 Act). There is nothing to suggest that the new titles were in substitution for anything less than the full expression of native title. It would hardly be consistent with "ownership... according to British law" if these Crown titles were to be encumbered by a host of vestigial "non-territorial" rights.

In practice, Maori claimants usually recited a range of activities performed on the land as proof of their entitlement to a freehold title. It seems incongruous to propose that, once the freehold title had been created, the right to conduct these activities survived as a burden on the new title, regardless of any later changes in ownership. It is surely contrived to suggest that deeds of purchase or Land Court orders might have overcome this by comprehensively listing all non-territorial incidents of title. The need to do this would not have been apparent at the time because neither the Legislature, the Native Land Court nor the practice of the Crown's representatives recognised the divisibility of native title, and hence the possibility of partial extinguishment. The idea that the Land Court occasionally acknowledged non-territorial incidents by appending fishing rights to titles is not supported by evidence. The only example cited appears to be the Whatapaka case. ${ }^{144}$ This has been interpreted as award of a fishing right when in fact the Court issued a conventional title to land above mean high water mark. The fact that this land was a shell bank does not mean that the award was a fishing right. ${ }^{145}$ A requirement of cataloguing all non-territorial incidents would have introduced great uncertainties into the law. How could one be sure that all possibilities had been covered? As Fenton almost foreshadowed in his judgment, it seems that the categories of non-territorial title are only limited by the resourcefulness of prospective litigants. The idea now being

the Native Land Court "shall be and be deemed to be in final extinguishment of the Native title" within the boundaries of the Ngaitahu (Kemp) purchase. The legislature clearly intended a bar to any future claims based on the "mahinga kai" exception in the deed. Given this two-step process of defining the exceptions and statutorily confirming the extinction of native title, it appears artificial to argue that other "non-territorial" rights, unspecified at that time, are still extant. See $P$ G McHugh "The Legal Basis for Maori Claims against the Crown" (1988) 18 VUWLR 1, 12.

144 P G McHugh "Aboriginal Servitudes and the Land Transfer Act 1952" (1986) 16 VUWLR 313, 324.

145 If it were the practice of the Court to record such rights, the irony would now be that rights deemed important enough to list are likely to have been conveyed or extinguished, while those not thought worthy of mention might now support a claim based on "non-territorial title". 
mooted that the principle in McRitchie extends to ownership rights in the water itself serves as an illustration. ${ }^{146}$

The argument for non-territorial titles in New Zealand also rests on other grounds. Much is made of the treatment of aboriginal rights under North American law. In order for this material to be relevant, however, it would be necessary to show that the creation of non-territorial titles in these jurisdictions bears analogy with the processes of identifying and extinguishing native title in New Zealand. This is a complex matter, and it is hoped to examine it more closely on another occasion. In the meantime, it suffices to note that the Kauwaeranga decision does not establish that such titles exist in New Zealand, at least as a result of partial extinguishment.

146 The idea is not, however, entirely new. While at Matamata in 1835, A N Brown recorded in his journal: "... soon after this another chief called on me to demand a payment for the water which our Girls are in the habit of fetching from a running stream in the neighbourhood, and in which he possesses only the common right of every Native of the place. I asked him in a good humoured way how much he wanted for the running water and for the rain and sunshine, as it would be best to make one payment for all three things. The Natives joined in a hearty laugh at the Chief in which he was obliged to join himself, and quietly gave up his claim." A N Brown Journal, 7 September 1835, MS 319, Alexander Turnbull Library. 


\section{CONCLUSION}

In the current debate over Maori rights, context has been an early casualty in the desire to press Kauwaeranga into service. The aim here has been to examine in more detail the circumstances of the decision. This limited exercise reveals several areas where a better appreciation of context may assist understanding. The short conclusion is that, without such examination, ancient precedents such as Kauwaeranga will contribute little to the resolution of modern legal questions. 